\title{
Relationship Lending and Credit Quality
}

\author{
Franco Fiordelisi $^{\mathrm{a}, \mathrm{b}}$, Stefano Monferrà ${ }^{\mathrm{c}}$, Gabriele Sampagnaro ${ }^{\mathrm{c}, *}$ \\ a. University of Rome III, Italy \\ b. Bangor Business School, UK \\ c. University of Naples "Parthenope", Italy
}

(15 January 2013)

\begin{abstract}
We analyze if the relationship lending reduces the borrower's probability of borrowers' default and if this beneficial effect operates also for those borrowers who are more exposed to the economic downturn. By using unique, matched data of 43,000 firms and their lending institutions between 2008 and 2010, we document that the probability that a firm becomes distressed decreases when the creditor concentration is high and the duration of bank- firm relationships is long. While these results seem to support the beneficial effect of the relationship lending practices, we note that the organizational distance of banks and collateral also matters both as determinants of loan distress and as determinants of loan downgrading. The results are stronger for smaller firms.
\end{abstract}

JEL classification: G21

Keywords: Probability of default; Relationship lending; Internal Rating

Acknowledgements: We thank Arnoud Boot, Olivier DeJonghe, Giorgio Gobbi, Phil Molyneux, Enrico Sette, Nikolas Papanikolaou, Anjan Thakor, Amine Tarazi, and the participants at the seminar of the Financial Intermediation of European Studies (FINEST) at the University of Rome III for helpful comments. We alone are responsible for remaining errors.

* Corresponding author: Department of Management, Via Medina 40, 80133 Napoli, Italy, tel, +390815474851; e.mail: gabriele.sampagnaro@uniparthenope.it, 


\section{Introduction}

Before the crisis erupted in 2007, relational lending had received great attention in the banking industry since the 1990s and it was commonly considered a good strategy to face increasing competitive pressures (e.g. single market program, substantial deregulation of structural market control, lower entry barriers etc.) in the European banking. Relationship banking refers to "the provision of financial services by a financial intermediary that: i) invests in obtaining customerspecific information, often proprietary in nature; and ii) evaluates the profitability of these investments through multiple interactions with the same customer over time and/or across products" (Boot 2000, p.10).

From a theoretical standpoint, prevalent theories (see for a review Boot, 2000; Degryes and Ongena, 2002; Ongena and Smith, 2000) suggest that relationship lending mainly aims to resolve agency problems and informational asymmetries by increasing the length of the relationship. This has obviously various benefits for banks since customers tend to become more profitable over time and fees and commission incomes increase. However, it is not clear if relationship lending would increase or reduce the credit quality of lending. On the one hand, it may be argued that a more concentrated relationship with lenders lowers the borrower probability to encounter a financial distress since higher creditor concentration improves bank monitoring and screening and lowers monitoring costs (Diamond 1984; see for a review Gorton and Winton, 2003). On the other hand, a closer bank-firm relationship may incentivize the lender to use the superior private information to extract rents, thus causing inefficient investment choices and possibly generated hold-up problem (Boot, 2000; Rajan, 1992; Sharpe, 1990). A second problem originated by an exclusive lenderborrower relationship is the soft-budget constraint that may lead the lender to refinance unprofitable projects and thus reduce entrepreneurial incentives to avoid financial distress (Dewatripont and Maskin, 1995). The facilitations of debt renegotiation occurred in tied relationships may affect negatively the efforts of the lender to enforce the credit contract (Bolton and Scharfstein, 1996).

The connection between relationship lending and the probability of a borrower to become insolvent is unclear also from the empirical standpoints. According to Elsas and Krahnen (1998), firms with long-standing relationship with a main bank might reap the benefit whatever the onset 
financial distress. Foglia et al. (1998) show that multiple lending practices is associated with a higher riskiness of the firm, supporting the hypothesis that when a large number of lenders are involved, monitoring of the borrower tends to be weaker and to encourage its fragility. Focusing on Spain, Jimenez and Saurina (2004) find that collateralized loans have a higher probability to fail and that an intense bank-borrower relationship increases the willingness to take more risk. Carmignani and Omiccioli (2007) show that high concentration of bank credit reduces the likelihood of financial distress and liquidation, as predicted by the literature on relationship banking. All these papers focus on periods before the crisis. Regarding the empirical strategy adopted, some papers (Elsas and Krahnen, 2000; Elsas 2005) use credit-file data and other papers (Carmignani and Omiccioli, 2007; Jimenez and Saurina, 2004) focus on industry survey studies conducted exclusively with data collected by the national credit register (specifically, these studies analyze the credit information between each firm within the entire bank system). While the latter approach has the unquestionable value of extending the results at bank system level, it fails to capture some characteristics of bankfirm relationship (e.g. the measure of borrower's risk) that can affect credit decisions importantly from a loan supply-side point of view. For example, in industry survey, the borrower's risk is extrapolated from balance-sheet data and it can therefore be distorted for various reasons such as: the greater opaqueness of small firms balance sheet, the low time-frequency of data, the leaving out of other dimensions of risk. On the contrary, credit-file data including private information hold by banks include internal rating system that enable one to make a better evaluation of borrower quality and potentially offers a number of new insights on the real value of financial relationships from a single-lender perspective.

This leads us to answer the following questions in the paper. Does relationship lending reduce the borrower's probability of default? And does this beneficial effect operate also for those borrowers who are more exposed to the economic downturn? We find that relational banking might enhance screening and monitoring of borrowers and offer a valuable practice to prevent borrowers' financial distress. As in a previous study, our empirical results shows that a closer and long relationship with lenders decreases the probability of default. We also consider as independent variable a measure of the geographical distance between the local branch and the bank headquarter 
to take into consideration the dispersion of soft information through the organizational layers of the bank as a further control of relational banking intensity. Nevertheless, while these results are stemming from data of one representative banking group and cannot be extended to the domestic banking industry, they raise questions regarding the role of relational lending in banking industry and its contribution to mitigate (or not) the negative effect on credit dynamics caused by the financial turmoil. We also show that closer bank-firm relationship helps to prevent borrower's financial distress also when the distress is mainly explained by the economic downturn. These findings are consistent with the improvement of lender monitoring and screening due to tied relationship between borrowers as predicted by prevalent theories about information asymmetries. However, while the our evidences might be useful to explore the role of bank-relationships also in time of crisis, one should take caution in drawing far-reaching conclusions due to the fact that results could be influenced by typical problems of endogeneity and simultaneous causality. Consequently, we perform 2SLS method to alleviate endogeneity issue and we find that our original results continue to hold.

We exploit a unique dataset (data about credit relationship for 43,000 Italian firms from 2008 to 2010) comprising private information hold by Italian banks such as creditor concentration, duration of relationship, internal rating, organizational distance, collateralization of debt and other loan contract terms. We analyze a data set representing a random sample of borrowers drawn from the credit portfolios of a large Italian banking group articulated in one parent company and seven subsidiaries. Our data set consists of a balanced panel data that gives a detailed account, of credit history for 43,338 firms over two years, from 2008 to 2010 (about 10\% of them results in default at the end of the period), including bank-internal borrower rating data to evaluate borrower quality. To our best knowledge, the balanced panel data employed in this analysis represents one of the richest in terms of number of borrowers observed over two years of turbulent environmental conditions.

We contribute to previous papers in three ways. First, the number of studies assessing the relationship between the borrower-lender distance and the borrower insolvency based on large sample of loans is very limited and there is a substantial need of empirical evidence. Second, we analyze the relationship between the borrower-lender distance and the borrower insolvency during 
the crisis whereas most of previous papers focus on periods before the crisis. Third, we focus on Italy, one of the largest European banking industries that has been deeply affected by the credit crisis, whereas previous studies focused on the US or other small banking industry. The Italian economy is an interesting subject of analysis for several reasons. For example, during the period examined (but also after it), the Italian government did not intervene to support domestic banks or firms after the crisis. Thus, both domestic loan supply and loan demand were not affected by external factors. Moreover, as Italian firms (especially small firms) are highly dependent on bank credit for both working capital and longer-term financing, they are very sensitive to any distortion in credit supply.

The remainder of the paper is organized as follow. In section I, we briefly review previous papers and develop our research hypotheses. Section II contains a description of the data set and variables. We present our econometric strategy in Sections III and our results in section IV. Section $\mathrm{V}$ discusses the main findings and conclusions.

\section{Literature review}

The role of the bank-customer relationship in credit risk has aroused a considerable amount of interest in the literature over the last two decades. Boot and Thakor (1994), Berger and Udell (1995), and Boot (2000) argue that prior lender-borrower relationships help reduce the information asymmetry between them, resulting in more flexible loan contract terms in future loans from prior relationship lenders.

The intensity of the bank-firm relationship can be approximated by the number of lending banks for the borrower, the share of the borrower's finance that each institution provides (or at least, the one provided by the main bank), or the duration of the credit relationship.

The impact of closer and more concentrated credit relationships on borrowers' creditworthiness is a subject debated in the financial intermediation literature. The relationship lending influences the borrowers' screening (Ramakrishnan and Thakor, 1984) and monitoring (Diamond, 1984). Specifically, since monitoring is costly, the incentive to acquire and assess the borrower's information is low in the case of multiple lending: the cost of acquisition of information 
would be paid by one bank, while the benefits would be shared by the others lenders (free riders). Savers delegate the task of monitoring to banks because of the lack of information about risk and of the earning outlook of borrowers. Resolving the friction of informational asymmetry between lender and borrower is all the more important, the least important being the borrower's standing. This is one of the reasons why banks tend to have a closer relationship with smaller businesses (Rajan, 1992). A closer (or exclusive) relationship with the lender facilitates monitoring and screening, carries important and beneficial implications such as the sector specialization (however costly) of the lenders (Boot and Thakor, 2000) that might lead to a lower ex post probability of financial distress (Carmignani and Omiccioli, 2007).

On the other hand, a close banking relationship may engender at least two drawbacks (Boot, 2000): the soft budget constraint and the liquidity risk. Since the higher creditor concentration facilitates the renegotiations of debt, borrowers may activate a perverse incentive to activate opportunistic behavior and risk-taking policies that, consequently, increase the probability of default. From the borrower's point of view, the liquidity risk issue may picture the single-banking relationship as a non-optimal solution. Detragiache et al. (2000) show that if there is a probability that bank-relationship ends, the borrower faces a serious adverse selection problem because outside lenders have less information and the removal of credit is likely to be interpreted as a problem with the borrowing firm (it is suspected of being a bad firm). If the adverse-selection problem is severe, firms may pay off to establish more, relationships, though asymmetric, with banks. This may be a serious problem especially for economies with high bankruptcy costs and in which banks rarely have liquidity problems.

As the number of lenders, the length of the lender-borrower relationship is another indicator of the intensity of credit relationship. The duration of the relationship is supposed to be directly connected to the intensity of the relationship because of the accumulation of information over time on the part of the bank. This is the position emerging from various empirical investigations (Berger and Udell, 1995; Petersen and Rajan, 1994) including that of Boot (2000), who shows the positive effects also from the point of view of the collateral required and interest rates applied. However, this hypothesis is not without uncertainties. In the event of a lengthy relationship, negative holdup 
phenomena can materialize (see Rajan, 1992). Furthermore, because the accumulation of information is not linear over time and the benefits increase in a way which is less than proportional to time (Diamond, 1991), it is not possible to exclude the possibility, in long-term relationships, that the borrower may be tempted to abandon them (Ongena and Smith, 2000). This also seems to be confirmed by Degryse and Van Cayseele (2000) who shows deterioration in contractual conditions applied to the debt as the duration of the relationship increases.

Another relevant issue is to establish the role of collateral as a potential predictor of risk. In other terms, the question is to investigate whether loans without collateral can be considered less risky than those with collateral. From a theoretical point of view, collateral can be interpreted as an attempt to either balance for ex ante asymmetric information or as a way of reducing ex post frictions (such as moral hazard concerns). Since the presence of an ex ante gap of information between the bank and the firm may conduct to adverse selection and credit rationing as described by Stiglitz and Weiss (1981), the ex ante theories predict that collateral permits lenders to sort observationally identical loan applicants through signaling. Specifically, when the quality of the borrower is unobservable, lenders prefer to offer a list of contract terms, including the pledge of collateral, able to self-select firms according to their risk perception. In equilibrium, low-quality applicants choose unsecured debt with higher interest rates while high-quality applicants self-select into secured debt with lower risk premiums (Bester 1985, 1987, Besanko and Thakor 1987a, 1987b, Chan and Thakor 1987). On the other hand, the ex post theories indicate that it is most probable that observably more risky borrowers are required to pledge collateral.

Boot, Thakor and Udell (1991) develop a model where secured loans are made to riskier borrowers. They argue that collateral pledged by risky borrowers induces them to increase managerial effort to avoid loan default, and thus limit the problem of moral hazard.

From the empirical standpoint, there are mixed findings about if bank-firm relationship determines whether collateral is pledged or not. Brick and Palia (2007) show that the probability of firm collateral requirement decreases with the length of bank-firm relationship. Similarly, Chakraborty and $\mathrm{Hu}$ (2006) find that the incidence of collateral pledge decreases with the number of lender-provided financial services used by the borrower. By contrast, other studies (Machauer and 
Weber 1998, Degryse and Van Cayseele 2000, Elsas and Krahnen 2002, Lehmann and Neuberger 2001, and Menkhoff et al. 2006, Ono and Uesugi 2009) find that collateral is contract- term prevalent into the relationship between the borrowers and their main bank. However, understanding the role of collateral during a financial crisis implies to take into consideration other motivation that induce the banker to prefer secured loans. As the financial crisis change the risk perception that a bank has of its borrower, and because the number of defaults has been increased tremendously in Italy between 2008 and 2010, the attention of bankers are more focused on regulatory capital management and on facing downward income. In this perspective, bank may ask collateral primarily to riskier firms as a tool to mitigate the LGD parameter and then the quote of capital absorbed for each loan.

The allocation of lending sector across relationship and transaction lending depends on interbank competition. In their model, Boot and Thakor (2000) suggest that as interbank competition increases, banks make more relationship loans but each loan has less added value for borrowers whereas a higher competition of capital market (bonds market) reduces relationship lending, although each loan has more added value for borrowers. However, the relationship between bank competition and borrower's default has been examined only indirectly by the existing literature on the issue of competition and stability in the banking industry. The weight of empirical evidence regarding indicators of banking market structure and bank risk taking is mixed, with no clear consensus. Boyd and De Nicoló (2005), unveil the existence of a fundamental risk-incentive mechanism that leads banks to take more risk as markets become more concentrated. This mechanism contemplates that, ceteris paribus, banks realize more rents by charging higher loan rates as competition in their loan markets declines. Thus, higher competition might imply (weakly) higher bankruptcy risk for bank borrowers. The positive relationship between the risk of borrower's default and market competition is further reinforced by the moral hazard of borrowers, which might optimally increase their own risk of failure due to higher interest costs.

The finding challenges the predictions made by previous studies, both theoretical and empirical, on the role of bank competition on bank risk - taking according to which as the number of 
banks becomes arbitrarily large, the optimal risk of failure reaches a maximum (Allen and Gale, 2000; Hellmann et al. 2000; Keeley 1990 and Repullo, 2003).

Based on previous studies, we posit and test the following two hypotheses:

$H_{1}$. As the relationship lending increases, the borrower's probability of default declines.

$\mathrm{H}_{2}$. As the market concentration increases (implying lower competition), the probability of default increases

\section{Data and variables}

In this section, we provide readers with detailed information about data and variable we use in the empirical analysis.

\subsection{Data}

We collected private-data from eight Italian banks (belonging to a great bank group operating all over Italy). The banking group is one of a handful of truly national banks operating in Italy. It lends to borrowers located in 106 out 110 provinces and operates in 165 industries (six-digit NACE classification). In our sample, $80 \%$ of the firms have a very small size (i.e. total assets lower than 2 million Euro), while the percentage of small firms in Italy in the same period is 95\% (ISTAT, 2009).

After checking for inconsistencies, outliers, duplicates of clients and random pattern of missing values, our sample is a balanced panel data of loans granted to 43,338 firms between the 31 December 2008 and 31 December 2010. This data is representative of the size of domestic manufacturing firms that, typically, apply for loans at local bank branches instead to tap into the bond or equity markets for their external financing. Since the analysis is at borrower-level, we match data at the starting date with data at the end of the period (December 2010) for each borrower ${ }^{1}$. Finally, an important filter added to data is that while firms at $t_{0+2}$ can be defaulted or not, all of

\footnotetext{
${ }^{1}$ More precisely, data used here are derived exclusively from the borrowers-banks relationship level. This means that we collect some information about the relationship that firm $\mathrm{i}(\mathrm{i}=1 . .43,338)$ holds with bank $\mathrm{j}(\mathrm{j}=1 . .8)$. According to our data, the loans are then aggregated at borrower level. The analysis with an aggregated measure of credit granted (a sum of line-of-credit loans and non lineof-credit loans for each borrower) represents one of the limitations of the survey data that prevent us from examining the role of the technical form of loans in determining its probability of default. Other important limitations refer to the lack of firm-specific variables except for the yearly sales, the size class, the industry and the province.
} 
them has no problematic loans in t. Since our database is provided by a banking group, we have to take into account the sample selection issue.

For each borrower, we have private information that is not available to credit-register as the bank risk evaluation in the internal rating system. The use of credit-file data, rather than industry survey studies, enables us to focus the analysis on information that is directly related to actual credit decisions (Elsas and Krahnen, 1998). The key variables in our dataset are the borrower riskiness and the solvency condition (distressed or not) at the end of the year. In order to control for firm characteristics, we collect data about firm as the total amount of sales, its geographical area (i.e. the province) and the industry where they operate. The time span, the availability of confidential data and the characteristics of the Italian financial landscape (where domestic banks have not received any government support during the financial crisis) make this data ideally suited to investigate whether relationship lending contributes and how it contributes to decrease loan deterioration. As other studies have recently observed (e.g. Gobbi and Sette, 2011), Italy is an ideal laboratory for this

kind of analysis, because the Italian financial system is bank-based and banks represent a fundamental partner of firms in providing funds.

\section{$<$ INSERT TABLE $1>$}

Table 1 provides summary statistics for the samples of firms separating them according to lenders and geographical area. About $10 \%$ of the firms in the sample switched to distressed condition at the end of the period. The distribution of distressed firms by size class is quite aligned with the overall distribution by size inside the overall sample, except for very small firms class for which the incidence of distressed firms is more pronounced (15.87\%).

\subsection{Variables}

The central point for any studies dealing with relationship lending is to objectively define it and measure the strength of relationship between borrowers and lenders. To measure the orientation of each bank to relationship lending, we focus on various indirect indicators of the intensity of the 
credit relationship as the length of lender-borrower relationship, the number of banks (Ongena and Smith, 2001 and 2000), and the geographical distance between headquarter and local branch of the lender (Jimenez et al., 2009).

To capture the length of the lender-borrower relationship, we build the variable LENGHT as the logarithm value of the duration (in years) of the credit relationship between the bank $\mathrm{j}$ and the firm $i$ calculated at the end of 2010. In cases where the credit relationship duration was less than one year, this is approximated at the value of one year.

To capture the number of banks lending to each borrower, we build the variable \#BANKS as the natural $\log$ of number of banks lending for firm $i(i=1, \ldots, 43,338)$ at time $\mathrm{t}_{0}$, and also before the default event. Since this number is obtained by the Italian Credit Register, it suffers from some signaling filters: specifically, banks granting firms for a loan smaller than 30,000 euro $^{2}$ are not recorded in the register and, therefore, in our variable.

The geographical distance between the bank and the firm is important since it influences the real availability of most of banking services. Loosely following Jimenez et al. (2009), we build the variable DISTANCE $E_{i j}$ as the $\log$ value of the distance between the province of the local bank branch serving the borrowers and the city where it is located the bank headquarter ${ }^{3}$.

A second central point in our study is to define the borrower's default. We follow the definition of Basel II Capital (2004) accord: receivables that are more than 90 days past due, where the debtor is legally proclaimed bankrupt, or that are considered probable not to be repaid in full, have to be flagged as defaulted. Consequently, we define the variable DEFAULT $\mathrm{t}_{0+2}$, as a binary variable that identifies if the borrower is in default $\left(\mathrm{DEFAULT}_{\mathrm{t} 0+2}=1\right)$ or not $\left(\mathrm{DEFAULT}_{\mathrm{t} 0+2}=0\right)$. To build this variable, we rely on the variable RATING ${ }_{t}$, which is an ordinal measure of the borrower's creditworthiness, representing the expected default probability as estimated by each lender. The

\footnotetext{
${ }^{2}$ The variables LENGHT and \#BANKS measures the strength of bank-firm relationship. However, having no information about the number of financial services provided by the lenders, we cannot follow the general definition of relationship banking advanced by Boot (2000) that defines it as: <<the provision of financial services by a financial intermediary that: $i$. invests in obtaining customerspecific information, often proprietary in nature; and $i$. evaluates the profitability of these investments through multiple interactions with the same customer over time and/or across products $>$, pp. 10

${ }^{3}$ In more formal terms, the following proxy of distance was used: DISTANCE $E_{i j}=\ln \left(1+\mathrm{KM}_{\mathrm{ij}}\right)$ where $K M_{i j}$ is the distance in kilometer between the province of firm $i$ (in Italy there are 110 provinces) and the Headquarter of bank $\mathrm{j}(\mathrm{j}=1 . .8$ ).
} 
banks' internal borrower ratings system is composed of 13 risk classes for solvent borrowers (i.e. $1=$ the less risky class; 13 = the worst) plus one class (defined as "D class") denoting default firms.

We construct the rating migration matrix exploited in the Table A.1 (see Appendix), where a greater propensity of firms with intermediate risk quality to become distressed emerges. We then code DEFAULT $\mathrm{t}_{\mathrm{t} 0+2}$ equal to 1 if the firm rating is $\mathrm{D}$ at the end of $2010\left(t_{0+2}\right)$ and the companies was not in default (i.e. its rating was between 1-13) at the end of $2008\left(\mathrm{t}_{0}\right)$. Note that all problematic firms labeled as "distressed" are discriminated by the internal credit risk system according the severity of the distress. In particular, this preliminary classification (has the advantage of marking) marks each borrower in one of six class of doubtful client, from the less severe to the most dramatic class. In class 1 fall borrowers with one or more loans remain unpaid three months after the date of maturity, or when there are reasonable doubts as to their repayment (past due loans). Class 6 contains defaulted claims while intermediate classes $(2,3,4$, and 5) classify delinquent loans in ascending order of severity.

We also include various control variables (related to the type of loans and the borrower characteristics) that are likely to influence the relationship between the relationship lending and the probability of default.

Regarding the type of loans, the dummy variable COLLAT captures if a firm has its loans collateralized in $\mathrm{t}_{0}(\mathrm{FIRM}=1)$ or otherwise. The variable OVERDRAWN is the ratio between credit used and credit granted (summing loans, accounts receivable, short-term loans, long-term loans and revolving credit lines ${ }^{4}$ ) from the bank $j$ to the firm $i$. This variable is usually interpreted as a metric for credit rationing: the ratio is higher than one when firms have drawn more credit than its commitments. As suggested by various papers using data from the Italian credit register (Buttiglione and Ferri, 1994; Bonaccorsi di Patti et al., 2003), this ratio expresses an inverse measure of credit availability and is typically used by banks to assess the firm's fragility: the higher the ratio, the higher is the likelihood that the firm is liquidity constrained. The Herfindahl-Hirschman index (HHI) measures the market power of the local credit market (computed in terms of bank branches) at

\footnotetext{
${ }^{4}$ A credit line is understood here as a contract that allows a borrower to take advantage of a predetermined line limit and repay the loan?at the borrower's discretion with an interest rate periodically set by the bank. Whenever the drawn credit exceeds the line limit, the bank charges a penalty interest rate.
} 
province level of firms. Following Fiordelisi et al. (2011), it is calculated as the as the sum of banks squared market shares in loans granted in each one of the Italian provinces in year 2010.

Regarding control variable related to borrowers, we collect the log value of sales at the end of 2008 and $2010\left(S A L E S_{t}\right)$ from each firm's balance sheet of the year before (respectively 2007 and $2009)^{5}$. We also consider the firm size using a categorical variable (four categories of size: very small, small, medium-sized and large) provided by the banks and that classify firms each year.

We also build a specific set of dummy variables to control for the borrower's industry (specifically, 164 dummies) and bank lenders (7 dummies) of firms.

Table 2 summarizes the main characteristics of variables described above and others dummies related to them.

\section{$<$ INSERT TABLE $2>$}

\section{Econometric strategy}

Our empirical approach is borrowed from (Jimenez and Saurina, 2004). The main econometric approach relies on a binomial probit model. The endogenous variable, Default $_{t+2}$, is binary and takes the value of 1 if the firm $i$ has all or a part of loans granted by bank $j(\mathrm{j}=1 . .8)$ doubtful at 12/31/2010 and 0 otherwise. This model can be summarized as:

$$
\operatorname{Pr}\left(\text { Default }_{t+2}\right)=\Phi\left(\begin{array}{l}
\beta_{0}+\beta_{k} \sum \text { RelatioshipVariable }_{i j t}+\beta_{k} \sum \text { BorrowerVar }_{i j t}+ \\
+\beta_{k} \sum \text { LoanTerms }_{i j t}+\beta \text { MarketPower }_{j}+\beta_{k} \sum \text { ControlVar }_{i j t}
\end{array}\right)
$$

where $\operatorname{Pr}$ stays for probability and subscripts $i, j$ and $t$ are indicative of firm $(i=1,2, . ., 43,338)$, lenders $(j=1,2, . ., 8)$ and time $(t=$ Dec/2008, Dec/2010), respectively.

Relationship variables include the number of lenders for each firm (\#BANK), the duration lender-borrower relationship (LENGTH), the distance between the headquarter and the lender and the location of the credit office where the firm holds the relationship (DISTANCE). Loan contract

\footnotetext{
${ }^{5}$ Except for Sales, the data of this study cannot be matched with firm balance-sheet data, for example, since the banking group altered the borrower identities before providing us the data for confidentiality purposes.
} 
terms variables include the bank-firm credit granted and credit used and the presence of collateralized loans. Market power is measured by the Herfindahl-Hirschman index. To control for other firm-specific variables, we add dummies to distinguish the size of a firm; we then saturate the specification with a bank fixed effect to control for bank unobserved characteristics that might affect lender behaviour during a crisis. Further, to account for unobserved time-varying firm loan demand and quality shocks, we also include fixed effects for industry.

\section{Relationship lending and probability of default}

In this section, we discuss our results regarding the relationship between firm's probability of default and relationship lending in Table 3. We test two main hypotheses and $\mathrm{H}_{2}$ ): the borrower's probability of default increases as the relationship lending decreases $\left(\mathrm{H}_{1}\right)$ and as the market concentration increases (implying lower competition).

\section{$<$ INSERT TABLE $3>$}

We find strong statistically significant evidence that relationship lending variables are related to the borrower's probability of default. Specifically, we find that an increase in the number of bank (a lower creditor concentration) is positively associated with the incidence of default firms. This result is broadly consistent with the informational argument according to which a large number of lenders reduces the incentive to monitoring (due to its higher costs in such situation) and facilitates the occurrence of asymmetric information and adverse selection risk.

As expected, the length of bank-firm relationship is negatively associated with the likelihood of a solvent firm in $t_{0}$ to switch to default firm in $t_{0+2}$. The marginal effect (at the mean) is -0.0068 indicating that a $0.68 \%$ increase in duration of relationship reduces of $1 \%$ the firm's probability of default. This is consistent with the idea that a strong bank-firm relationship facilitates value-enhancing exchange of information (Boot, 2000) supporting the beneficial effect of relationship lending. 


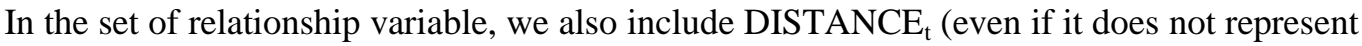
a pure indicator of relationship lending as the previous two variables): its estimated marginal effect is positive and supports the idea that a longer distance between firms and the bank decisional center (i.e. its headquarter) would be detrimental for the credit worthiness of firms. Long distance could imply a dissipation of soft information (due to their difficulty of being transmitted), it follows that in a period of credit shock, firms funded by banks with a strong vertical organizational structure obtain fewer benefits from a relationship banking model. As exploited in Table 4, where we split the sample according to firm size, the empirical impact of distance is very significant only for very small firms (column 1). Generally, this class of firms is characterized by higher opaqueness (due to weak financial statements or collateral of doubtful value) and they have more need for local (and close) credit officers with sufficient responsibility and autonomy in the loan approval process.

The positive sign and statistical significant value of the HHI coefficient suggest that in more concentrated markets (with less competition) the likelihood of default is higher than in lessconcentrated ones. The interpretation of this result is disputable. At a first glance, it seems to support the idea that monopolistic banks are more exposed to local risk, and then to firm's default (Boyd and De Nicolò, 2005). However, a more robust reading should take into account both some interactions between market concentration and bank organizational structure, as provided by Presbitero and Zazzaro (2011), and detection of the potential presence of non-monotonic effect of competition as revealed by Elsas (2005) and Degryse and Ongena (2007) .

Focusing on the control variables, we find that the borrower's risk (measured by RATING $\mathrm{t}_{\mathrm{t}}$ ), is the most powerful predictor of firm failure. The positive value of its marginal effect is explained by recalling numerical orders of RATING ${ }_{\mathrm{t}}$ firms at time $t_{0}$ with best creditworthiness have rating 1 while worst firms has rating 13. In column 2 of Table 3, we also included some variables related to loan contracts. This inclusion causes a substantial dropping in the number of observations prevalently due to missing value $\triangle$ OVERDRAWN. In this case, all estimated coefficients for the relationship lending variables hold their sign, confirming the positive role of a close bank-firm relationship in preventing default event. The only exception regards DISTANCE that loses its

\footnotetext{
${ }^{6}$ However, we omit to run this analysis since it is beyond the scope of this paper.
} 
previous high statistical significance (its sign changes from positive to negative, too). Recalling that DISTANCE $_{\mathrm{t}}$ works better for very small firms (column 1 in Table 4 ) due to their higher opaqueness and, consequently, the higher dissipation of soft information through the different organizational layer of the lenders, the poor statistical significance of this variable can be explained by the sample restriction. When we pass from specification (1) to specification (2) we assist to a considerable dropping in observations especially for smallest borrowers: while overall sample goes from 43338 to 18978 , very small firms class goes from 19,131 to 3,631 observations.

Regarding COLLAT, we estimate a positive coefficient that is statistically significant at $5 \%$. While this result could be quite consistent with an ex-ante role of collateral to mitigate asymmetric information for riskier borrowers, much caution has to be taken in this interpretation since this variable is not statistically significant in all specifications employed in subsequent sections. As expected, $\triangle$ OVERDRAWN and $\triangle$ CREDIT controls efficiently for credit flows frictions triggered by the onset of problematic event. To prevent the default event, firms experiencing financial crisis ask massively for a credit amount greater than the offer (OverDrawn rise up), while the unavailability of lenders to cope with new credit lines firms characterized by doubtful creditworthiness signals ( $\triangle$ CREDIT falls) worsens the financial equilibrium of borrowers and increases the likelihood of default. These mechanisms seem to be well explained by the positive sign of $\triangle$ OVERDRAWN and the negative sign of $\triangle$ CREDIT, both statistically significant at $1 \%$.

We find that variables capturing the size of the borrowers are highly related to its probability of default. As such, we split our sample in four subsamples according to the borrower's asset size in order to measure the contribution of relationship lending practice in determining the probability of the borrower's default (Table 4).

\section{$<$ INSERT TABLE $4>$}

Our new results are strongly consistent with the main results with two considerable exceptions. As anticipated before, the variable DISTANCE has a statistical significance and positive coefficient for very small firms only. This is truly consistent with the tendency of lenders to collect 
primarily soft information for this type of client due to their higher opaqueness in terms of hard information (weak financial statements or collateral of doubtful value). As local knowledge is difficult to quantify and transmit (especially for banks that are geographically diversified with a complex organizational structure), it tends to be dispersed when communicated through different organizational layers of the banks. Thus, a long distance between the local branch, gathering qualitative information, and the headquarters of the banks (where the main credit officers are generally located) is positively associated with the financial distress of small firms, especially in times of financial turmoil. The second main exception that we mentioned is related to LENGTH that assumes positive (and statistically significant value) for all firm's size except for large firms. This evidence is in line with our expectations because it confirms theories and evidences that depict relationship lending as a peculiar lender's behavior reserved for medium and small firms (Elsas, 2005).

However, we admit that the observed pattern of probability of default could be determined by some observable or unobservable characteristics of the borrowing firm, which in turn may affect our results. The key issue for the tests conducted so far is that these results could suffer of usual problems of endogeneity, reverse causation and omitted variables. Specifically, the length of the borrower-lender relationship represents our most relevant problem because it could be endogenous to the borrower's risk ${ }^{7}$. The lack of convincing instruments or lagged explanatory variables prevents us from interpreting the regression results as incontrovertible causal relationships.

In Table 5, we split the same specification considering the bank-firm relationships of the parent bank with those of the subsidiaries separately. It is worth mentioning that all subsidiaries have a smaller size of parent banks. While we suspect the presence of a unique credit policy for the overall banking group, it should be noted that screening and monitoring activities are autonomous in each subsidiary (that were single banks before the acquisition) and that the geographical areas they serve are well differentiated. Columns (1) and (2) of Table 5 show regularity of results with the exception of DISTANCE that obtains a statistically significant value only for subsidiaries. Also, the

\footnotetext{
${ }^{7}$ Banks could be encouraged to have a long relationship with a better firm: consequently, the reduction of probability of default should be interpreted as the cause rather than the effect of relationship lending.
} 
linkage between distance and small firms discussed above and the different weight of very small firms along the two sub-samples, can explain the result in this specific case. Specifically, the share of very small firms in subsidiaries is $59 \%$ of the sub-sample while it is $38 \%$ for the parent bank ${ }^{8}$.

\section{$<$ INSERT TABLE $5>$}

\section{Addressing endogeneity concerns}

The observed pattern of probability of default could be determined by some observable or unobservable characteristics of the borrowing firm, which in turn may affect our results. The key issue for the tests conducted so far is that these results could suffer of usual problems of endogeneity (simultaneous causality). Specifically, the most relevant problem in our case is represented by the length of the borrower-lender relationship because it could be endogenous to the borrower's quality. One potential solution is to use an instrument that is correlated with the duration of relationship but does not affect the dependent variable $\left(\right.$ DEFAULT $\left._{t 0+2}\right)$ directly except through length of the borrower-lender relationship.

Thus, to address the potential endogeneity of long relationship with respect of unobserved characteristics of each firm $i$, a two-stage least squares (2SLS) estimation is carried out as robustness check. In a first-stage regression we use the instrument to predict the length of the borrower-lender relationship (endogenous variable); the predicted value is then used as a regressor in the secondstage default regression.

We employ as instrumental variable the number of firms (NumFIRMs) calculated at province and industry levels and can be considered as a proxy of local competition faced by borrowers. Specifically, for each firm $i$ of our sample, NumFIRMs containing the number of firms existing in the province and the industry of firm $i^{9}$. We suggest that this variable is likely to be negatively correlated with the length of bank-firm relationship (endogenous variable) to the extent high number of firms for a specific industry in a specific province reduce the likelihood that the

\footnotetext{
${ }^{8}$ We omitted to detail the frequency of firm size classes for each lenders for reason of brevity.

${ }^{9}$ We calculate NumFIRMS using the statistic services provided by The Italian Union of Chambers of Commerce, Industry and Crafts (Unioncamere) matched with province level data provided by the demographic services of ISTAT.
} 
lenders entertaining a longest relationship due to the higher competition (lenders have more chance to substitute borrowers in the same, possibly profitable, industry). In the first-stage regression, we examine the determinants of a firm to entertaining a long relationship with lenders. The results of this first-stage probit model are provided in Table 6 (column 1). The first stage $F$-statistic is 49.6 and reject the null that the coefficients on the instrument are insignificantly different from zero (at the $1 \%$ level). We also perform the Wald test to see if the length of bank-firm relationship is exogenous, obtaining that the null hypothesis that the latter is exogenous is strongly rejected ( $p$-value $=0.000$ ).

\section{$<$ INSERT TABLE $6>$}

We argue that the propensity of forming a long relationship would decrease as the competition at industry and province level increases. Consistent with this, we obtain a negative coefficient for NumFirms (-0.05) significant at the $1 \%$ level. These results suggest that NumFIRMS appears to be correlated with duration of relationship to be considered as acceptable instrument. Column (3) of Table 6 report also the results of IV regression. In column (2) we reproduce our benchmark probit regression (previously reported in Table 3) while column (3) of Table 6 reports the IV regression results. The results of IV estimation confirm our previous findings: a long and not fragmented relationship with the lender decreases the probability of default while higher concentration of bank credit actually used reduces this likelihood. Except for DISTANCE, the other variables in iv regression hold the same sign captured by the previous probit model (2) and are all statistical significant at $1 \%$ level.

\section{Economic downturn and additional evidences}

Our results show the beneficial role of closer bank-firm relationship in decreasing the probability of the firm's default. However, these results do not say anything about the ability of relationship lending to prevent borrower's financial distress during the crisis. To address this issue, one would have to compare the lender's behavior over time (i.e. before and during the crisis) and space (i.e. discriminating between business failures caused by the economic downturn and businesses that 
would fail anyway). Since we have not had access to such data, we propose various alternative tests to detect if and how relationship lending is beneficial for borrowers more exposed to the financial turmoil.

Firstly, we order industry in our dataset by default's rate in descending order. Industry positioned on the top has the highest ratio between the number of sample firms defaulted at $t_{0+2}$ and the population of that industry. Then, we select firms belong to industries on the left of the median value of the cumulative distribution of the default's rate. The belief is that by restricting our analysis to this sub-sample of firms we will be able to make some consideration about the ability of relationship lending to mitigate the effect of the financial turmoil. Column 1 of Table 7 reports results of the extension of our econometrical strategy applied to the restricted sample. With the

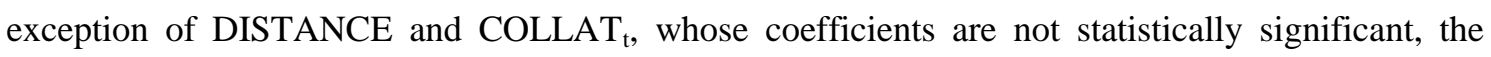
results are unchanged and provide a preliminary support in favor of the benefits descending from intense lender-borrower relationships. However, we add a more severe sample restriction in column 2 where we extend the previous econometric specification to a sample consisting of firms filtered both by industry and by rating. Specifically, we consider firms of industries with highest default rate and with a rating range of 1 to 6 at the time $t_{0}$ (the period previous to the default). This filter reduces the number of firms to $5,486,177$ of which are defaulted firm at $t_{0+2}$. Since the latter set of borrowers consists of firms that experienced an eight rating notches downgrade or more ${ }^{10}$, the belief is that a large part of them have heavily suffered the economic downturn. Outcomes reported in column 2 (Tables 6) show that while all variables hold the previous sign, LENGTH and DISTANCE are not statistically significant anymore. Though these findings do not reject evidences in favor of relationship lending pointed out up to here (\#BANKS hold their predictive ability), especially in the light of the severity of the sub-sample restriction, it suggests much caution and additional testing to examine the issue of bank-firm relationships during a crisis.

\section{$<$ INSERT TABLE $7>$}

\footnotetext{
${ }^{10}$ Since D (default) corresponds to the fourteenth class of the rating bank system.
} 
We turn now to detect the determinants of a firm's risk downgrading. The basic idea is to track the creditworthiness of firms from 2008 to 2010 through internal rating change. Then, we select a sub sample consisting of those firms that have experienced a downgrade. Formally, a new variable has been built: $\{\Delta$ RATING $=[\operatorname{Rating}(2010)-\operatorname{Rating}(2008)]\}$ if Rating(2010)>Rating(2008).

The transition to an upper class (more risky) rating represents a negative event both from the borrower's and the lenders' point of view (respectively due to the increase of probability of default and of the cost of regulatory capital). The same can be said for the worst case of downgrading, i.e. firm's insolvency, it is plausible to expect a beneficial role of relationship lending also for the other cases of credit risk deterioration To examine this issue, we run OLS regression in the attempt to measure the contribution of relationship and other determinants to the borrower's risk decline following the specification (1) reported in Table 8.

To isolate the incidence of closer bank-firm relationship for firms more exposed to the financial turmoil, we then extend this specification to a restricted sub-sample obtained applying conjointly the two following filters: a) we consider only industries in the lower half of the cumulative distribution of the default's rate (as done in the previous Table 3); b) we select firms with rating less than the median value, at time $t_{0}$ (i.e. good firms in $\mathrm{t}_{0}$ downgraded in $t_{1}$ ).

Results displayed in Table 8 show that the signs and significance of relationship-control variables are generally consistent with the main results obtained up to now. Data reported in column 1 suggest that a short and parceled relationship with lenders is positively correlated with credit risk deterioration also during a financial turmoil (see Column 2 of Table 8).

\section{$<$ INSERT TABLE $8>$}

\section{Conclusions}

This paper has analyzed the influence of some characteristics of bank-firms relationships with the borrower's probability of default. Specifically, we have examined the role of creditor concentration, duration of lender -borrower relationship, distance, collateral and interbank competition trying to 
identify the hypothesis that best explains the impact of such variables on the probability of that loans becoming delinquent.

Our analysis focuses on the Italian credit market, a bank-dependent economy, in the midst of an extended financial crisis. We use data collected from the credit files of seven banks belonging to one Italian banking group characterized by a discrete level of autonomy (each bank has a separated credit business unit) and well-differentiated between them by geographical area, sector specialization and size of investments. The data set contains general company characteristics, specific loan contract characteristics and the bank's assessment of borrower default probability (internal ratings) of an initial sample of 43,338 firms.

First of all, our findings confirm that higher concentration of lenders and longer banking relationship lowers the likelihood for the firm to encounter financial distress. These results are very highly statistically significant in all specifications and robustness checks (except for the duration of bank-firm relationship that results non significant in just one specification). In accordance with the theoretical predictions, we find that this effect is stronger for smaller firms probably due to their higher opaqueness. Secondly, as pointed out by the results of our main regression, the distance between the branch were the loan originated and the bank headquarter (c.d. organizational distance) seems to positively contribute to the borrower's default probability. This result is much stronger for smallest firms, and may reflect the idea that the long internal distance between the bank's organizational makes difficult the exchange of qualitative and soft information. Consequently, firms in financial distress typically may find it much more difficult to receive additional funds and expertise by lenders to solve their problems.

Furthermore, interbank competition also seems to have a role in determining probability of default to the extent that a highly concentrated market is associated to a higher risk of borrower's default. This result appears consistent with the theoretical mechanism drawn by Boyd and De Nicolò (2005) where, when the loans market is very concentrated, borrower's can suffer from higher interest rates that can incentivize them both to raise the borrowers' debt loads and to engage in riskier projects (consistently with the moral hazard à la Stiglitz and Weiss, 1981). 
The role of collateral is also explored. Since our results show a positive and statistically significant (at 5\%) association between collateral and ex post probability of default only in one specification (and insignificant values in all other specifications) we found weak support for the symmetry theories (Boot et al., 1991) suggesting that in case of symmetry between the bank and the borrower, collateral will be demanded from riskier borrowers, or for screening theories (Manove and Padilla, 1999, 2001), according to which collateral might decrease screening efforts by the lenders at the time of loan origination.

We also find some indication about the contribution of relationship lending in the midst of the crisis. Specifically we extended our econometrical model to a sub-sample of borrowers consisting of firms of sectors with the highest rate of default over two years of observation. A more restricted filter was then employed restricting the previous sub-sample to those firms that downgraded by at least two notches during the period (2008-2010). Besides, there is clear evidence that creditor concentration is inversely correlated to the probability of default confirming our previous findings. 


\section{References}

Allen, F. and Gale, D. (2000). Comparing Financial Systems. Cambridge, MA: MIT Press.

Berger, A. and Udell, G. F. (1995). "Relationship lending and lines of credit in small firm finance", Journal of Business 68, 351-381.

Besanko, D. and A. V. Thakor (1987a). "Competitive Equilibrium in the Credit Market under Asymmetric Information,” Journal of Economic Theory, 42, 167-183.

Besanko, D and A. V. Thakor (1987b). "Collateral and Rationing: Sorting Equilibria in Monopolistic and Competitive Credit Markets," International Economic Review, 28, 671689.

Bester, H., (1985). "Screening vs. Rationing in Credit Markets with Imperfect Information," American Economic Review, 75, 850-855.

Bester, H. (1987). "The Role of Collateral in Credit Markets with Imperfect Information," European Economic Review, 106, 60-75.

Bolton, P., Scharfstein, D., (1996). Optimal debt structure and the number of creditors. Journal of Political Economy 104, 1-25.

Bonaccorsi di Patti, E., Gaiotti, E. and Lotti, F., (2003), "Rallentamento degli impieghi e condizioni del mercato del credito: una rassegna degli indicatori", mimeo, Bank of Italy.

Boot, A. W. A., and Thakor, A. V. (2000). "Can relationship banking survive competition," Journal of Finance 55, 2, 679-713

Boot, A. W. A., and Thakor, A. V., (1994). "Moral hazard and secured lending in an infinitely repeated credit market game," International Economic Review 35, 899-920.

Boot, A.W.A., 2000. "Relationship banking: what do we know?," Journal of Financial Intermediation 9, 7-25.

Boot, A.W.A., Thakor, A.V., and Udell, G. F., (1991). "Secured Lending and Default Risk: Equilibrium Analysis, Policy Implications and Empirical Results," Economic Journal, 101, 458-472.

Boyd, J.H. and De Nicolò, G., (2005). "The theory of bank risk taking and competition revisited," Journal of Finance 60, 3, 1329-1343.

Brick, I.E., and Palia, D. (2007). "Evidence of jointness in the terms of relationship Lending," Journal of Financial Intermediation, 16, 452-476.

Buttiglione, L., and Ferri, G., (1994). "Monetary Policy Transmission via Lending Rates in Italy: Any Lesson from Recent Experience?”, Working Paper: Bank of Italy 224.

Carmignani, A., and Omiccioli, M. (2007). "Costs and benefits of creditor concentration: An empirical approach,” Working Paper: Bank of Italy 645.

Chakraborty, A., and Hu, C., (2006). "Lending relationships in line-of-credit and nonline-ofcredit loans: Evidence from collateral use in small business," Journal of Financial Intermediation 15, 86-107.

Chan, Y.S., and Thakor A.V., (1987). "Collateral and Competitive Equilibria with Moral Hazard and Private Information," Journal of Finance, 42, 345-363.

Cotugno, M., Monferrà, S., Sampagnaro, G. (2012). "Relationship lending, hierarchical distance and credit tightening: Evidence from the financial crisis". Journal of Banking \& Finance, http://dx.doi.org/10.1016/j.jbankfin.2012.07.026

Degryse, H., Van Cayseele, P., (2000). "Relationship lending within a bank-based system: Evidence from European small business data," Journal of Financial Intermediation 9, 90-109. 
Degryse, H., Ongena, S. (2002). "Bank-Firm Relationships and International Banking Markets," International Journal of the Economics of Business, 9, 401-417.

Degryse H. and Ongena, S., (2007). "The impact of competition on bank orientation," Journal Financial Intermediation, 16, 399-424

Detragiache, E., Garella, P., Guiso, L., (2000). "Multiple vs. single banking relationships: theory and evidence," Journal of Finance 55, 1133-1161.

Dewatripont, M., and Maskin, E. (1995). "Credit and efficiency in centralized and decentralized economies," Review of Economic Studies, 62, 541-555.

Diamond, D. (1984). "Financial intermediation and delegated monitoring," Rev. Review of Economic Studies, 51, 393-414.

Diamond, D. (1991). "Monitoring and reputation: The choice between bank loans and privately placed debt," Journal of Political Economy, 99, 689-721.

Diamond, D. W., (1991). "Debt Maturity Structure and Liquidity Risk," Quarterly Journal of Economics, 106, 709-737.

Elsas, R., Krahnen, J.P., (1998). "Is relationship banking special? Evidence from credit-file data in Germany," Journal of Banking \& Finance, 22, 1283-1316.

Elsas, R. and Krahnen, J. P. (2000). "Collateral, Default Risk, and Relationship Lending: an Empirical Study on Financial Contracting,” CEPR, Discussion Paper 2540.

Elsas, R., (2005). "Empirical determinants of relationship lending," Journal of Financial Intermediation 14, 32-57.

Fiordelisi, F., Marques-Ibanez, D. and P. Molyneux, (2011). "Efficiency and Risk in European Banking," Journal of Banking and Finance 35, 1315-1326.

Foglia, A., Laviola, S., Marullo Reedtz, P., (1998). 2Multiple banking relationships and the fragility of corporate borrowers", Journal of Banking \& Finance 22, 1441-1456.

Gobbi, G., Sette, E., (2011). "Do Firms Benefit From Concentrating Their Borrowing? Evidence From the Great Recession," Mimeo, Bank of Italy.

Gorton, G. and Winton, A. (2003). "Financial intermediation". In: Constantinides G, Harris M and Stultz M (ed.) Handbooks in the Economics of Finance, Vol. 1A. Amsterdam: Elsevier Science

Hellmann, K, Murdock, C. and Stiglitz, J.E., (2000). "Liberalization, moral hazard in banking, and prudential regulation: Are capital requirements enough?" American Economic Review $90,147-165$.

ISTAT, (2009). "Struttura e competitività del sistema delle imprese industriali e dei servizi", published on 27th October 2011, www.istat.it

Jimenez, J. and Saurina, J., (2004). "Collateral, type of lender and relationship banking as determinants of credit risk", Journal of Banking and Finance, 28, 2191-2212.

Jimenez, G., Lopez, J.A., and Saurina, J., (2007). "How does competition impact bank risktaking?" Federal Reserve Bank of San Francisco. Working Paper No. 23.

Jimenez, G., Salas, V., Saurina, J., 2009. "Organizational distance and use of collateral for business loans," Journal of Banking \& Finance 33, 234-243.

Keeley, M.C., (1990). "Deposit insurance, risk, and market power in banking," American Economic Review, 80, 1183-1200.

Lehmann, E., and Neuberger, D., (2001). "Do Lending Relationships Matter?: Evidence from Bank Survey Data in Germany," Journal of Economic Behavior and Organization, 45(4): 339-359. 
Machauer, A. and Weber M. (1998). "Bank Behavior Based on Internal Credit Ratings of Borrowers," Journal of Banking and Finance, 22(10-11): 1355-1383.

Manove, M., Padilla, A.J., (1999). "Banking (conservatively) with optimists," RAND Journal of Economics 30, 324-350.

Manove, M., Padilla, A.J., (2001). "Collateral versus project screening: A model of lazy banks," RAND Journal of Economics 32 (4), 726-744.

Menkhoff, L., Neuberger, D. and Suwanaporn, C. (2006). "Collateral-Based Lending in Emerging Markets: Evidence from Thailand," Journal of Banking and Finance, 30(1): 1-21.

Ongena, S., Smith, D.C., (2000). "What determines the number of bank relationships? Crosscountry evidence," Journal of Financial Intermediation 9 (1), 26-56.

Ongena, S., Smith, D.C., (2001), "The Duration of Bank Relationships," Journal of Financial Economics, 61, 449-475.

Ono, Arito and lichiro Uesugi (2009). "The Role of Collateral and Personal Guarantees in Relationship Lending: Evidence from Japan' s SME Loan Market," Journal of Money, Credit and Banking, 41(5): 935-960.

Petersen, M., Rajan, R.G., (1994). "The benefit of lending relationships: evidence from small business data," Journal of Finance 49, 1367-1400.

Presbitero, A. F. and Zazzaro, A. (2011). "Competition and relationship lending: Friends or foes?,” Journal of Financial Intermediation 20, 3, 387-413.

Rajan, R., (1992). "Insiders and outsiders: The choice between informed and arm's length debt," Journal of Finance 47, 13671400

Ramakrishnan, T.S., and Thakor, A.V., (1984). "Information Reliability and a Theory of Financial Intermediation," The Review of Economic Studies , 51, 3, 415-432.

Repullo, R., (2003). "Capital requirements, market power, and risk-taking in banking," Discussion Paper no 3721, CEPR.

Sharpe, S. (1990). "Asymmetric information, bank lending and implicit contracts: A stylized model of customer relationships," Journal of Finance 45, 1069-1087.

Stiglitz, J., and Weiss, A., (1981). "Credit rationing in markets with imperfect information," American Economic Review 71, 393-410. 
Table 1

Sample Description

\begin{tabular}{|c|c|c|c|c|c|c|c|c|c|}
\hline \multirow[b]{3}{*}{ Parent company } & \multirow[b]{2}{*}{ (Firms) } & \multirow[b]{2}{*}{ (Default) } & \multicolumn{4}{|c|}{ Firm Size } & \multicolumn{3}{|c|}{ Geographic Area } \\
\hline & & & $(\mathrm{VS} f)$ & $(\mathrm{S} f)$ & $(\mathrm{M} f)$ & $(\mathrm{L} f)$ & $(\mathrm{N})$ & (C) & $(\mathrm{S} \& \mathrm{I})$ \\
\hline & 28,968 & 2,220 & 10,730 & 11,527 & 6,198 & 513 & 3,749 & 25,019 & 200 \\
\hline Subsidiary Bank 1 & 6,973 & 1,630 & 5,640 & 938 & 365 & 30 & 330 & 771 & 5,872 \\
\hline Subsidiary Bank 2 & 4,399 & 279 & 1,587 & 1,706 & 1,066 & 40 & 22 & 98 & 4,279 \\
\hline Subsidiary Bank 3 & 1,801 & 142 & 674 & 775 & 346 & 6 & 11 & 26 & 1764 \\
\hline Subsidiary Bank 4 & 486 & 50 & 225 & 188 & 70 & 3 & 2 & 481 & 3 \\
\hline Subsidiary Bank 6 & 350 & 5 & 132 & 139 & 75 & 4 & 3 & 347 & 0 \\
\hline Subsidiary Bank 6 & 268 & 34 & 109 & 134 & 24 & 1 & 1 & 265 & 2 \\
\hline Subsidiary_Bank 7 & 93 & 15 & 34 & 41 & 16 & 2 & 1 & 5 & 87 \\
\hline $\begin{array}{r}\text { Total } \\
(\%) \\
{[\%]}\end{array}$ & $\begin{array}{c}43,338 \\
(100)\end{array}$ & $\begin{array}{l}4,375 \\
(10.1)\end{array}$ & $\begin{array}{l}19,131 \\
(44.1) \\
{[15.9]}\end{array}$ & $\begin{array}{c}15,448 \\
(35.6) \\
{[4.8]}\end{array}$ & $\begin{array}{c}8,160 \\
(18.8) \\
{[6.8]}\end{array}$ & $\begin{array}{c}599 \\
(1.4) \\
{[7]}\end{array}$ & $\begin{array}{c}4,119 \\
(9.5) \\
{[12.6]}\end{array}$ & $\begin{array}{c}27,012 \\
(62.3) \\
{[45.4]}\end{array}$ & $\begin{array}{c}12,207 \\
(28.2) \\
{[42]}\end{array}$ \\
\hline
\end{tabular}

Note:

(Firms) is the number of firms solvent in $t$ while (Default) represents the number of firms distressed at $t+1$; (VSf) indicates very small firms; $(\mathrm{S} f)$ means small firms, while $(\mathrm{M} f)$ and $(\mathrm{L} f)$ mean respectively medium-sized and large firms. (N), (C) and (S\&I) indicate respectively the North, the Centre and the South (with Isles) of Italy. Squared brackets report the percentage of firm distressed at class size and geographic level. 
Table 2

Summary of variables

\begin{tabular}{|c|c|c|c|c|c|c|}
\hline Name & Description & Mean & Median & Min & Max & No. Obs \\
\hline \#BANKS $_{\mathrm{i}}$ & The natural log of lending banks for firm $i(i=1 . .43,338)$ & 1.25 & 1.10 & 0 & 2.94 & 43,338 \\
\hline LENGHT $_{i j}$ & $\begin{array}{l}\text { The natural log of the length (in years) of the credit relationship } \\
\text { between the bank } j(j=1 . .8) \text { and the firm } i(\mathrm{i}=1 . .43,338) \text { at the end of } \\
2010 \text {. }\end{array}$ & 1.98 & 1.95 & 0.69 & 3.26 & 43,338 \\
\hline DISTANCE $_{i j}$ & $\begin{array}{l}\text { The natural log of }(1+\mathrm{km}) \text {, where } \mathrm{km} \text { indicates kilometers between } \\
\text { the province of local branch with which firm } \mathrm{j} \text { has relationships and } \\
\text { the city of } \mathrm{j} \text { bank's headquarters. }\end{array}$ & 3.31 & 3.89 & 0 & 6.88 & 43,338 \\
\hline $\mathrm{HHI}_{j}$ & $\begin{array}{l}\text { Market power: Herfindahl-Hirschman index of bank } j \text { branches } \\
(\mathrm{HHI}) \text { at province level }\end{array}$ & 6.80 & 6.59 & 5.95 & 8.14 & 43,338 \\
\hline COLLAT $_{t}$ & $\begin{array}{l}\text { Dummy that has the value of } 1 \text { if the firm } i \text { has collateral with the } \\
\text { bank } j\end{array}$ & 0.05 & 0 & 0 & 1 & 43,338 \\
\hline \multirow{2}{*}{ RATING $_{i j t}$} & \multirow{2}{*}{$\begin{array}{l}\text { Internal rating (log value) of firm } i \text { calculated by bank } j \text {. It has } \\
\text { twelve categories where a rating of } 1 \text { is the best quality, and a } \\
\text { rating of } 13 \text { is worst. }\end{array}$} & 1.79 & 1.67 & 0 & 2.56 & 43,338 \\
\hline & & 1.79 & 1.59 & 0 & 2.56 & 38,533 \\
\hline \multirow{2}{*}{$\mathrm{CREDIT}_{i j t}$} & \multirow{2}{*}{$\begin{array}{l}\text { Sum (log value) of line-of-credit loans and non-line-of-credit } \\
\text { loans for firm } i \text { from bank } j \text { at time } t \text {. }\end{array}$} & 11.84 & 12.01 & 9.62 & 15.67 & 42,868 \\
\hline & & 11.56 & 11.60 & 7.86 & 15.55 & 39,118 \\
\hline \multirow{2}{*}{ OVERDRAWN $_{i j t}$} & \multirow{2}{*}{ Credit drawn/Credit granted ratio related to firm $i$ and bank $j$} & 0.75 & 0.66 & 0 & 1.32 & 42,811 \\
\hline & & 0.74 & 0.66 & 0 & 1.55 & 39,118 \\
\hline \multirow{2}{*}{ SALES $_{i t}$} & \multirow{2}{*}{$\begin{array}{l}\text { The natural } \log \text { of Sales extracted by balance sheets }(2007 \\
\text { and 2009) for firm } i \text {. }\end{array}$} & 13.91 & 14.01 & 9.10 & 18.57 & 30,814 \\
\hline & & 13.82 & 13.92 & 9.95 & 18.41 & 28,193 \\
\hline Vey Small Firms & $\begin{array}{l}\text { Dummy with value of } 1 \text { if the firm has a turnover less than } 2 \text { million } \\
\text { EUR and number of workers }<10\end{array}$ & 0.44 & 0 & 0 & 1 & 43,338 \\
\hline Small Firms & $\begin{array}{l}\text { Dummy with value of } 1 \text { if the firm has a turnover between } 2 \text { and } 5 \\
\text { million EUR and number of workers }<50\end{array}$ & 0.36 & 0 & 0 & 1 & 43,338 \\
\hline Medium_sized & $\begin{array}{l}\text { Dummy with value of } 1 \text { if the firm has a turnover between } 5 \text { and } 50 \\
\text { million EUR and number of workers }<250\end{array}$ & 0.19 & 0 & 0 & 1 & 43,338 \\
\hline Large Firms & $\begin{array}{l}\text { Dummy with value of } 1 \text { if the firm has a turnover more than } 50 \\
\text { million EUR }\end{array}$ & 0.01 & 0 & 0 & 1 & 43,338 \\
\hline
\end{tabular}

where the subscripts $i, j$ and $t$ denotes the firm $(i=1,2, . .43,338)$, the lenders $(j=1,2, . ., 8)$ and the time $(t=$ Dec/2008, Dec/2010), respectively. 


\section{Table 3}

The relationship between the probability of Default and banking relationship in the Italian banking industry: the whole sample

\begin{tabular}{|c|c|c|c|c|}
\hline & \multicolumn{2}{|c|}{ Model (1) } & \multicolumn{2}{|c|}{ Model (2) } \\
\hline & (a) & (b) & (a) & (b) \\
\hline & Coefficient & Marginal Effects & Coefficient & Marginal Effects \\
\hline \multirow{2}{*}{ \#BANKS $_{\mathrm{t}}$} & $0.2856^{* * *}$ & $0.0332 * * *$ & $0.1364 * * *$ & $0.0053^{* * *}$ \\
\hline & $(0.0185)$ & $(0.0021)$ & $(0.0402)$ & $(0.0016)$ \\
\hline \multirow{2}{*}{ LENGHT $_{t+1}$} & $-0.0586^{* * *}$ & $-0.0068 * * *$ & $-0.0579 * *$ & $-0.0022 * *$ \\
\hline & $(0.0129)$ & $(0.0015)$ & $(0.0291)$ & $(0.0011)$ \\
\hline \multirow{2}{*}{ DISTANCE } & $0.0156^{* * *}$ & $0.0018 * * *$ & $-0.0157 *$ & $-0.0006^{*}$ \\
\hline & $(0.0043)$ & $(0.0005)$ & $(0.0095)$ & $(0.0003)$ \\
\hline \multirow{2}{*}{ RATING $_{\mathrm{t}}$} & $0.8852 * * *$ & $0.1030 * * *$ & $1.1062 * * *$ & $0.0437 * * *$ \\
\hline & $(0.0225)$ & $(0.0023)$ & $(0.0516)$ & $(0.0022)$ \\
\hline \multirow{2}{*}{$\mathrm{HHI}_{\mathrm{t}}$} & $0.1293^{* * *}$ & $0.0150 * * *$ & $0.1648 * * *$ & $0.0065 * * *$ \\
\hline & $(0.0247)$ & $(0.0028)$ & $(0.0561)$ & $(0.0022)$ \\
\hline \multirow{2}{*}{ COLLAT $_{t}$} & & & $0.2259 * *$ & $0.0089 * *$ \\
\hline & & & $(0.0903)$ & $(0.0036)$ \\
\hline \multirow{2}{*}{ CREDIT $_{\mathrm{t}}$} & & & 0.0223 & 0.0008 \\
\hline & & & $(0.0234)$ & $(0.0009)$ \\
\hline \multirow{2}{*}{$\triangle \mathrm{CREDIT}$} & & & $-0.1423 * * *$ & $-0.0056^{* * *}$ \\
\hline & & & $(0.0212)$ & $(0.0009)$ \\
\hline \multirow{2}{*}{$\triangle$ OVERDRAWN } & & & $0.1202 * * *$ & $0.0047 * * *$ \\
\hline & & & $(0.0197)$ & $(0.0007)$ \\
\hline \multirow{2}{*}{$\triangle$ SALES } & & & -0.0067 & -0.0002 \\
\hline & & & $(0.0198)$ & $(0.0007)$ \\
\hline \multirow{2}{*}{ LARGE FIRM } & $-0.5021 * * *$ & $-0.0584 * * *$ & & \\
\hline & $(0.0927)$ & $(0.0108)$ & & \\
\hline \multirow{2}{*}{ MEDIUM FIRM } & $-0.3397 * * *$ & $-0.0395 * * *$ & -0.1233 & -0.0048 \\
\hline & $(0.0328)$ & $(0.0038)$ & $(0.1391)$ & $(0.0055)$ \\
\hline \multirow{2}{*}{ SMALL FIRM } & $-0.443 * * *$ & $-0.0516^{* * *}$ & -0.1113 & -0.0044 \\
\hline & $(0.0239)$ & $(0.0028)$ & $(0.1543)$ & $(0.0061)$ \\
\hline \multirow{2}{*}{ VERY SMALL FIRM } & & & -0.1786 & -0.0070 \\
\hline & & & $(0.1724)$ & $(0.0068)$ \\
\hline \multirow{2}{*}{ Constant } & $-5.3584 * * *$ & & $-6.8444 * * *$ & \\
\hline & $(0.4784)$ & & $(0.7788)$ & \\
\hline INDUSTRY DUMMIES & Yes & Yes & Yes & Yes \\
\hline LENDERS DUMMIES & Yes & Yes & Yes & Yes \\
\hline No. observations & & & 18,978 & \\
\hline Log likelihood & & 40.9 & -2586.7 & \\
\hline LR chi2(180) & & 5.5 & 1123.8 & \\
\hline Prob > chi2 & & 00 & 0.0000 & \\
\hline Pseudo R2 & & 19 & 0.1785 & \\
\hline
\end{tabular}




\section{Table 4}

The relationship between the probability of Default and banking relationship in the Italian banking industry: the whole sample: firmsize subsamples

\begin{tabular}{|c|c|c|c|c|}
\hline Sub-samples & $\begin{array}{c}\text { Very Small } \\
\text { Firms }\end{array}$ & Small Firms & $\begin{array}{c}\text { Medium_sized } \\
\text { Firms }\end{array}$ & Large Firms \\
\hline${ } \mathrm{BANKS}_{\mathrm{t}}$ & $\begin{array}{c}0.2970 * * * \\
(0.0236)\end{array}$ & $\begin{array}{c}0.3222 * * * \\
(0.0385)\end{array}$ & $\begin{array}{c}0.2785 * * * \\
(0.0421)\end{array}$ & $\begin{array}{c}0.6323 * * * \\
(0.1588)\end{array}$ \\
\hline $\mathrm{LENGHT}_{\mathrm{t}+1}$ & $\begin{array}{c}-0.1243 * * * \\
(0.0154)\end{array}$ & $\begin{array}{c}-0.0858 * * * \\
(0.0267)\end{array}$ & $\begin{array}{c}-0.1511 * * * \\
(0.0345)\end{array}$ & $\begin{array}{l}-0.0975 \\
(0.1238)\end{array}$ \\
\hline DISTANCE & $\begin{array}{c}0.0319 * * * \\
(0.0052)\end{array}$ & $\begin{array}{c}0.0022 \\
(0.0092)\end{array}$ & $\begin{array}{c}-0.0184 \\
(0.0131)\end{array}$ & $\begin{array}{l}-0.0298 \\
(0.0565)\end{array}$ \\
\hline RATING $_{\mathrm{t}}$ & $\begin{array}{c}0.5994 * * * \\
(0.0279)\end{array}$ & $\begin{array}{l}1.0821 * * * \\
(0.0470)\end{array}$ & $\begin{array}{c}1.2507 * * * \\
(0.0571)\end{array}$ & $\begin{array}{l}1.2819 * * * \\
(0.2732)\end{array}$ \\
\hline $\mathrm{HHI}_{\mathrm{t}}$ & $\begin{array}{c}0.3237 * * * \\
(0.0185)\end{array}$ & $\begin{array}{c}0.1376 * * * \\
(0.0347)\end{array}$ & $\begin{array}{l}-0.0104 \\
(0.0501)\end{array}$ & $\begin{array}{l}0.4036^{*} \\
(0.2068)\end{array}$ \\
\hline Constant & $\begin{array}{c}-4.6256^{* * * *} \\
(0.1607)\end{array}$ & $\begin{array}{c}-4.8105 * * * \\
(0.2762)\end{array}$ & $\begin{array}{c}-3.7444 * * * \\
(0.3904)\end{array}$ & $\begin{array}{c}-7.7161 * * * \\
(1.6893)\end{array}$ \\
\hline No. observations & 19,131 & 15,448 & 8,160 & 599 \\
\hline Log likelihood & -7758.7 & -2543.8 & -1572.4 & -125.0 \\
\hline LR chi2(180) & 1222.07 & 871.37 & 904.89 & 54.13 \\
\hline Prob $>$ chi 2 & 0.0000 & 0.0000 & 0.0000 & 0.0000 \\
\hline Pseudo R2 & 0.0730 & 0.1462 & 0.2234 & 0.1779 \\
\hline
\end{tabular}




\section{Table 5}

The relationship between the probability of Default and banking relationship in the Italian banking industry: Parent vs. Subsidiaries banks

\begin{tabular}{lcc}
\hline & Parent Bank & Subsidiary Bank \\
\hline \#BANKS $_{\mathrm{t}}$ & $0.3952^{* * *}$ & $-0.1066 * * *$ \\
& $(0.01929)$ & $(0.0252)$ \\
LENGHT $_{\mathrm{t}+1}$ & $-0.1569^{* * *}$ & $-0.1002 * * *$ \\
& $(0.0175)$ & $(0.0176)$ \\
DISTANCE & 0.0014 & $0.0355 * * *$ \\
& $(0.0064)$ & $(0.0059)$ \\
RATING $_{\mathrm{t}}$ & $1.6060^{* * *}$ & $0.3834 * * *$ \\
& $(0.0367)$ & $(0.0277)$ \\
HHI $_{\mathrm{t}}$ & $0.1604 * * *$ & $0.0954 * * *$ \\
& $(0.0435)$ & $(0.0282)$ \\
Constant & $-5.8019 * * *$ & $-2.2904 * * *$ \\
& $(0.2972)$ & $(0.2321)$ \\
\hline No. observations & 28,968 & 14,370 \\
Log likelihood & -6020.0 & -5908.4 \\
LR chi2(180) & 3630.28 & 330.05 \\
Prob $>$ chi2 & 0.0000 & 0.0000 \\
Pseudo R2 & 0.2317 & 0.0272 \\
\hline
\end{tabular}

All models are estimated by a probit regression. Standard errors are reported in parentheses. All variables are described in the Table $2 . *$, **, *** denote that the estimated coefficient is statistically significant at $10 \%, 5 \%$ and $1 \%$ levels, respectively. 
Table 6

Instrumental variables regression estimation

Dep. Variable: Default $t_{t+1}(1 / 0)$

Instrumented variable: LENGHT $_{t+1}$

\begin{tabular}{|c|c|c|c|}
\hline & \multirow{2}{*}{$\begin{array}{c}\text { Coefficients } \\
\text { First Stage Regression } \\
(1)\end{array}$} & \multicolumn{2}{|c|}{ Coefficients } \\
\hline & & $\begin{array}{l}\text { Probit } \\
(2)\end{array}$ & $\begin{array}{l}\text { IV } \\
(3)\end{array}$ \\
\hline LENGHT $_{t+1}$ & & $\begin{array}{c}-0.0586 * * * \\
(0.0129)\end{array}$ & $\begin{array}{c}-0.9381919 * * * \\
(0.0758528)\end{array}$ \\
\hline \#BANKS $_{\mathrm{t}}$ & $\begin{array}{c}-0.0502862 * * * \\
(0.0072429)\end{array}$ & $\begin{array}{c}0.2856 * * * \\
(0.0185)\end{array}$ & $\begin{array}{c}0.1751642 * * * \\
(0.0230277)\end{array}$ \\
\hline DISTANCE & $\begin{array}{c}-0.053346 * * * \\
(0.0016505)\end{array}$ & $\begin{array}{c}0.0156 * * * \\
(0.0043)\end{array}$ & $\begin{array}{c}-0.0399015 * * * \\
(0.0064251)\end{array}$ \\
\hline RATING $_{\mathrm{t}}$ & $\begin{array}{c}-0.1780844 * * * \\
(0.0060975)\end{array}$ & $\begin{array}{c}0.8852 * * * \\
(0.0225)\end{array}$ & $\begin{array}{c}0.5279897 * * * \\
(0.0562926)\end{array}$ \\
\hline $\mathrm{HHI}_{\mathrm{t}}$ & $\begin{array}{c}-0.1093098 * * * \\
(0.0115129)\end{array}$ & $\begin{array}{c}0.1293 * * * \\
(0.0247)\end{array}$ & $\begin{array}{c}0.0957922 * * * \\
(0.0220914)\end{array}$ \\
\hline LARGE (1/0) & $\begin{array}{c}0.2165766^{* * * *} \\
(0.0320168)\end{array}$ & $\begin{array}{c}-0.5021 * * * \\
(0.0927)\end{array}$ & $\begin{array}{c}-0.2156948^{* *} \\
(0.086201)\end{array}$ \\
\hline MEDIUM (1/0) & $\begin{array}{c}0.0100592 \\
(0.0120366)\end{array}$ & $\begin{array}{c}-0.3397 * * * \\
(0.0328)\end{array}$ & $\begin{array}{c}-0.2616603 * * * \\
(0.0316452)\end{array}$ \\
\hline SMALL (1/0) & $\begin{array}{c}-0.1014758 * * * \\
(0.0084727)\end{array}$ & $\begin{array}{c}-0.443 * * * \\
(0.0239)\end{array}$ & $\begin{array}{c}-0.4362533 * * * \\
(0.0232352)\end{array}$ \\
\hline VERY SMALL (1/0) & & & \\
\hline Constant & $\begin{array}{c}2.903389 * * * \\
(0.1041609)\end{array}$ & $\begin{array}{c}-5.3584 * * * \\
(0.4784)\end{array}$ & $\begin{array}{c}-2.012109 * * * \\
(0.5359807)\end{array}$ \\
\hline$\frac{\text { Instrumental variable }}{\text { NumFIRMs }}$ & $\begin{array}{l}-3.46 \mathrm{e}-06 \\
(2.06 \mathrm{e}-07)\end{array}$ & & \\
\hline $\begin{array}{l}\text { INDUSTRY DUMMIES } \\
\text { LENDERS DUMMIES }\end{array}$ & $\begin{array}{l}\text { Yes } \\
\text { Yes }\end{array}$ & $\begin{array}{l}\text { Yes } \\
\text { Yes }\end{array}$ & $\begin{array}{l}\text { Yes } \\
\text { Yes }\end{array}$ \\
\hline $\begin{array}{l}\text { Obs } \\
\text { F- statistic } \\
\text { Prob }>F \\
R^{2}\end{array}$ & $\begin{array}{l}43337 \\
49.64 \\
0.0000 \\
0.1715\end{array}$ & $\begin{array}{l}\text { Obs } \\
\text { Pseudo } R^{2} \\
\text { Wald chi2(180) } \\
\text { Prob > chi2 }\end{array}$ & $\begin{array}{c}43337 \\
-57855.697 \\
7737.45 \\
0.0000\end{array}$ \\
\hline & & $\begin{array}{l}\text { Wald's test chi square } \\
\text { (p-value) }\end{array}$ & $\begin{array}{c}66.44 \\
(0.0000)\end{array}$ \\
\hline
\end{tabular}

Standard errors are reported in parentheses. * Significant at $10 \%$ level.

** Significant at $5 \%$ level.

*** Significant at $1 \%$ level. 
Table 7

Lender-borrower relationships and financial crisis: Sample Restrictions

\begin{tabular}{|c|c|c|c|c|}
\hline \multirow[t]{4}{*}{ Sample restrictions } & \multicolumn{2}{|c|}{$\begin{array}{l}\text { Industries with the } \\
\text { highest default rate }\end{array}$} & \multicolumn{2}{|c|}{$\begin{array}{c}\text { Industries with highest default rate } \\
\text { and } \\
\text { firms with best rating in } t \\
\text { (i.e. } 0<\text { RATING<7) }\end{array}$} \\
\hline & \multicolumn{2}{|c|}{ Model (1) } & \multicolumn{2}{|c|}{ Model (2) } \\
\hline & (a) & (b) & (a) & (b) \\
\hline & Coefficient & Marginal Effects & Coefficient & Marginal Effects \\
\hline \multirow[t]{2}{*}{ \#BANKS } & $0.3841 * * *$ & $0.0364 * * *$ & $0.3271 * * *$ & $0.0153 * * *$ \\
\hline & $(0.0444)$ & $(0.0043)$ & $(0.0745)$ & $(0.0035)$ \\
\hline \multirow[t]{2}{*}{ LENGTH } & $-0.1014 * * *$ & $-0.0096 * * *$ & -0.0355 & -0.0016 \\
\hline & $(0.0331)$ & $(0.0031)$ & $(0.0565)$ & $(0.0026)$ \\
\hline \multirow[t]{2}{*}{ DISTANCE } & 0.0112 & 0.0010 & 0.0204 & 0.0009 \\
\hline & (0.0106) & $(0.0010)$ & $(0.0181)$ & $(0.0008)$ \\
\hline \multirow[t]{2}{*}{ RATING } & $1.0385 * * *$ & $0.0985^{* * *}$ & $0.6162 * * *$ & $0.0288 * * *$ \\
\hline & $(0.0604)$ & $(0.0052)$ & $(0.1160)$ & $(0.0048)$ \\
\hline \multirow[t]{2}{*}{ HHI } & $0.1543 * *$ & $0.0146 * *$ & $0.1869 *$ & $0.0087 *$ \\
\hline & $(0.0614)$ & $(0.0058)$ & $(0.1038)$ & $(0.0048)$ \\
\hline \multirow[t]{2}{*}{ COLLAT } & -0.1092 & -0.0103 & -0.1604 & -0.0075 \\
\hline & $(0.1132)$ & $(0.0107)$ & $(0.1807)$ & $(0.0084)$ \\
\hline \multirow[t]{2}{*}{ CREDIT } & $0.0558 * *$ & $0.0052 * *$ & $0.0622 *$ & $0.0029 *$ \\
\hline & $(0.0224)$ & $(0.0021)$ & $(0.0382)$ & $(0.0017)$ \\
\hline \multirow[t]{2}{*}{ OVERDRAWN } & $0.3298 * * *$ & $0.0313 * * *$ & $0.3404 * * *$ & $0.0159 * * *$ \\
\hline & $(0.0751)$ & $(0.0071)$ & $(0.1187)$ & $(0.0055)$ \\
\hline \multirow[t]{2}{*}{ LARGE FIRM } & & & -0.3136 & -0.0147 \\
\hline & & & $(0.2495)$ & $(0.0116)$ \\
\hline \multirow[t]{2}{*}{ MEDIUM FIRM } & 0.0965 & 0.0091 & $-0.4028 * * *$ & $-0.0188 * * *$ \\
\hline & $(0.1439)$ & $(0.0136)$ & $(0.1409)$ & $(0.0066)$ \\
\hline \multirow[t]{2}{*}{ SMALL FIRM } & 0.0816 & 0.0077 & $-0.3128 * * *$ & $-0.0146 * * *$ \\
\hline & $(0.1595)$ & $(0.0151)$ & $(0.1061)$ & $(0.0050)$ \\
\hline \multirow[t]{2}{*}{ VERY SMALL FIRM } & $0.3667 * *$ & $0.0348 * *$ & & \\
\hline & $(0.1718)$ & $(0.0163)$ & & \\
\hline \multirow[t]{2}{*}{ Constant } & $-6.174 * * *$ & & $-5.2307 * * *$ & \\
\hline & $(0.6918)$ & & $(1.0326)$ & \\
\hline LENDERS DUMMIES & Yes & & Yes & \\
\hline Obs & 8829 & & 5486 & \\
\hline Log likelihood & -2146.8 & & -689.2 & \\
\hline LR chi2(180) & 938.50 & & 185.23 & \\
\hline Prob > chi 2 & 0.0000 & & 0.0000 & \\
\hline Pseudo R2 & 0.1794 & & 0.1185 & \\
\hline
\end{tabular}

All models are estimated by a probit regression. Standard errors are reported in parentheses. In the columns (a), the discrete variables are treated as continuous variables. All variables are described in the Table 2. *, **, $* * *$ denote that the estimated coefficient is statistically significant at $10 \%, 5 \%$ and $1 \%$ levels, respectively. 


\section{Table 8}

Determinants of Credit Risk Change (i.e. $\Delta$ RATING $^{-}=\mathrm{RATING}_{\mathrm{t}+1}-\mathrm{RATING}_{\mathrm{t}}$ )

\begin{tabular}{|c|c|c|}
\hline Sample restrictions & Firms with RATING $_{t+1}>R A T I N G_{t}$ & $\begin{array}{c}\text { Firms with } \text { RATING }_{t+1}>R \operatorname{ATING}_{t} \& \\
0<R A T I N G_{t}<7\end{array}$ \\
\hline \#BANKS $_{\mathrm{t}}$ & $\begin{array}{c}0.1717 * * * \\
(0.0383)\end{array}$ & $\begin{array}{c}0.2374 * * * \\
(0.0737)\end{array}$ \\
\hline LENGHT $_{t+1}$ & $\begin{array}{c}-0.1446 * * * \\
(0.0257)\end{array}$ & $\begin{array}{c}-0.1679 * * * \\
(0.0527)\end{array}$ \\
\hline DISTANCE & $\begin{array}{c}0.0072 \\
(0.0089)\end{array}$ & $\begin{array}{c}0.0010 \\
(0.0178)\end{array}$ \\
\hline RATING $_{\mathrm{t}}$ & $\begin{array}{c}-0.3176 * * * \\
(0.0385)\end{array}$ & $\begin{array}{c}-0.3380 * * * \\
(0.0788)\end{array}$ \\
\hline $\mathrm{HHI}_{\mathrm{t}}$ & $\begin{array}{l}0.1102^{*} \\
(0.0571)\end{array}$ & $\begin{array}{c}0.1757 \\
(0.1158)\end{array}$ \\
\hline Collat $_{\mathrm{t}}$ & $\begin{array}{l}-0.0712 \\
(0.0994)\end{array}$ & $\begin{array}{l}-0.2138 \\
(0.1483)\end{array}$ \\
\hline OVERDRAWN Ratio $_{t+1}$ & $\begin{array}{c}1.2146 * * * \\
(0.0759)\end{array}$ & $\begin{array}{c}1.3501 * * * \\
(0.1031)\end{array}$ \\
\hline$\triangle$ SALES & $\begin{array}{c}-0.0798 * * * \\
(0.0254)\end{array}$ & $\begin{array}{l}-0.0597 \\
(0.0473)\end{array}$ \\
\hline LARGE FIRM & $\begin{array}{c}-1.1871 * * * \\
(0.1718)\end{array}$ & $\begin{array}{c}-1.7548 * * * \\
(0.3933)\end{array}$ \\
\hline MEDIUM FIRM & $\begin{array}{c}-0.8419 * * * \\
(0.0685)\end{array}$ & $\begin{array}{c}-1.3119 * * * \\
(0.1376)\end{array}$ \\
\hline SMALL FIRM & $\begin{array}{c}-0.6278^{* * *} \\
(0.0512)\end{array}$ & $\begin{array}{c}-1.1228 * * * \\
(0.1070)\end{array}$ \\
\hline Constant & $\begin{array}{c}1.9775 * * * \\
(0.5545)\end{array}$ & $\begin{array}{c}2.4493 * * * \\
(0.9169)\end{array}$ \\
\hline $\begin{array}{l}\text { INDUSTRY DUMMIES } \\
\text { LENDERS DUMMIES }\end{array}$ & $\begin{array}{l}\text { Yes } \\
\text { Yes }\end{array}$ & $\begin{array}{l}\text { Yes } \\
\text { Yes }\end{array}$ \\
\hline $\begin{array}{l}\text { Obs } \\
R^{2}\end{array}$ & $\begin{array}{l}8,213 \\
0.1597\end{array}$ & $\begin{array}{c}6,253 \\
0.2360\end{array}$ \\
\hline $\begin{array}{l}\text { All models are estimated } \\
\text { columns (a), the discrete } \\
\text { Table } 2 . *, * *, * * * \text { denot } \\
\text { respectively. }\end{array}$ & $\begin{array}{l}\text { OLS regression. Robust Stand } \\
\text { ables are treated as continuous } \\
\text { the estimated coefficient is stati }\end{array}$ & $\begin{array}{l}\text { rors are reported in parentheses. I } \\
\text { les. All variables are described in } \\
\text { y significant at } 10 \%, 5 \% \text { and } 1 \% \text { le }\end{array}$ \\
\hline
\end{tabular}




\section{Appendix}

Table A.1

TwoYear Credit Rating Transition Matrix (2008-2010)

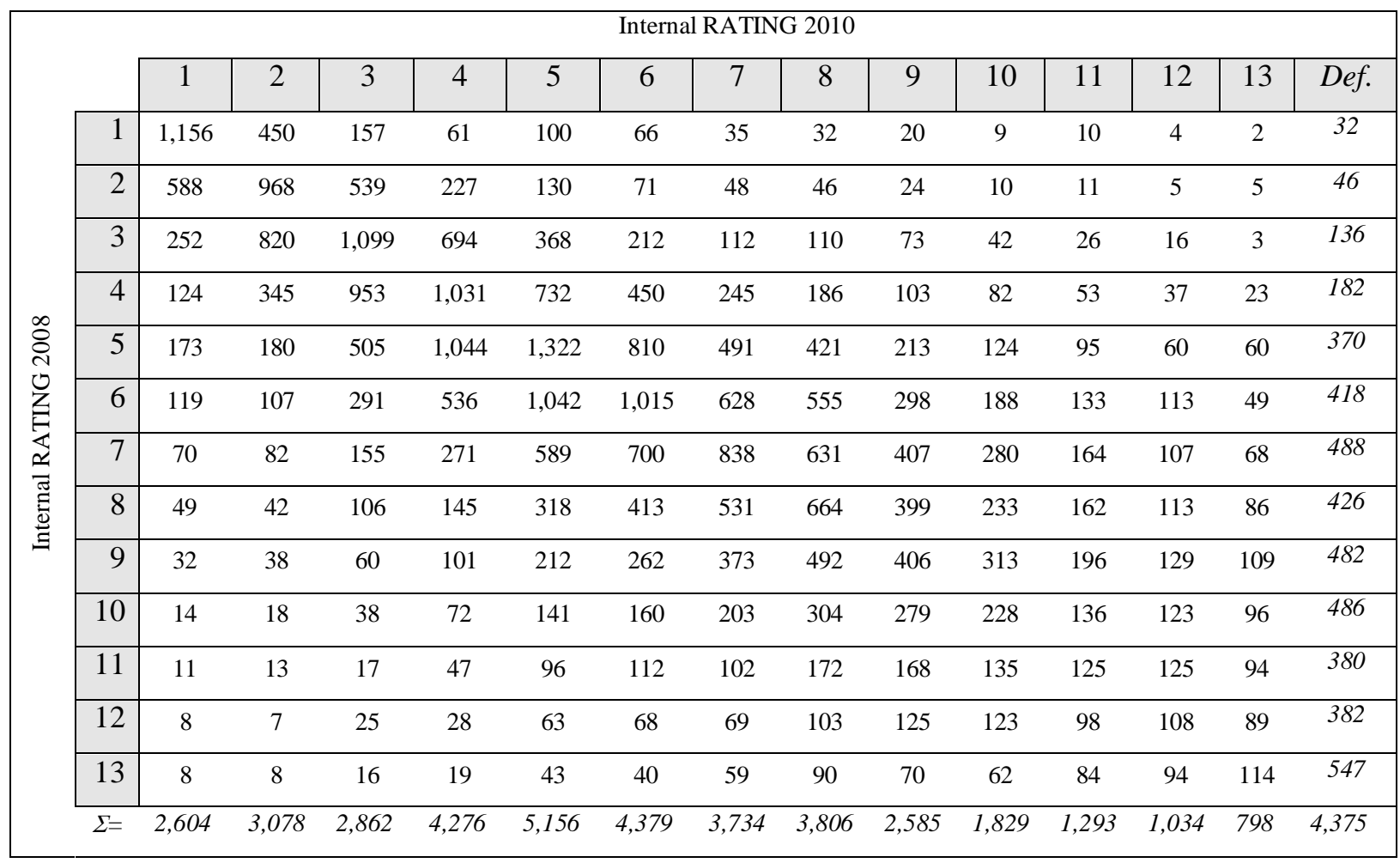

